\title{
Effect of Light Emitted by Smartphones at Bedtime on Circadian Rhythm and Sleep: Is It Different between Day Worker and Shift Worker?
}

\author{
Dongyeop Kim ${ }^{1}$, Hyunjin $\mathrm{Jo}^{1}$, Su Jung Choi ${ }^{2}$, Eun Yeon Joo ${ }^{1}$ \\ ${ }^{1}$ Department of Neurology, Neuroscience Center, Samsung Medical Center, Sungkyunkwan University School of Medicine, Seoul, \\ ${ }^{2}$ Graduate School of Clinical Nursing Science, Sungkyunkwan University, Seoul, Korea
}

\author{
야간 스마트폰 사용이 상근자와 교대근무자의 일주기 리듬과 수면에 미치는 영향 \\ 김동엽 ${ }^{1}$, 조현진 ${ }^{1}$, 최수정 ${ }^{2}$, 주은연 ${ }^{1}$ \\ 성균관대학교 의과대학 삼성서울병원 신경과 뇌신경센터, ${ }^{1}$ 성균관대학교 임상간호대학원 ${ }^{2}$
}

\begin{abstract}
Received February 4, 2021
Revised March 1, 2021

Accepted March 12, 2021
\end{abstract}

Address for correspondence Eun Yeon Joo, MD, PhD Department of Neurology,

Samsung Medical Center,

Sungkyunkwan University

School of Medicine,

81 Irwon-ro, Gangnam-gu,

Seoul 06351, Korea

Tel: $+82-2-3410-3599$

Fax: +82-2-3410-0052

E-mail: eunyeon.joo@gmail.com
Objectives: Light at night (LAN) can suppress melatonin secretion and thus disturb normal sleep. The aim of this study was to investigate how the illumination of a smartphone at bedtime affects the circadian rhythm and sleep in patients with insomnia. Methods: We recruited two middle-aged patients (one day worker and one shift worker) with insomnia. They used a smartphone more than 12 hours a day, particularly at bedtime. This was a crossover design study, and each patient spent a night at the light control unit twice at a one-week interval, with or without smartphone use. Patients were instructed to look at a smartphone (5-10 lux) under 150 lux of ceiling illumination from 18:00 until lights-off. During the night, without a smartphone, they read a book or newspaper. Saliva was collected every 30 minutes and analyzed for melatonin. Sleep was monitored by polysomnography. Results: The day worker showed a delayed dim light melatonin onset time (DLMO) (21:30 vs. 22:00) and a 38.7\% decrease in melatonin levels with smartphone use. For the shift worker, both melatonin and cortisol showed abnormal patterns, and thus DLMO was not determined in either condition. In the day worker, shorter rapid eye movement (REM) latency and increased REM were observed with smartphone use. Conclusions: This study demonstrates that the use of smartphones at bedtime acutely suppresses melatonin secretion and delays the sleep-wake cycle. However, the effect of LAN on melatonin secretion was not apparent in the shift worker with already misaligned circadian rhythm.

J Sleep Med 2021;18(1):29-36
서 론

빛공해란 불필요하거나 필요 이상의 인공조명에 의해 인 간과 자연 환경에 피해를 주는 것을 말한다. 현대 사회의 급 속한 기술 발전과 함께 빛공해는 새로운 환경오염의 한 종류 로 급부상하였으며, 빛공해가 인체 건강에 미치는 영향이 점 차 밝혀지고 있다. 야간 인공조명이 멜라토닌 분비를 억제시

This is an Open Access article distributed under the terms of the Creative Commons Attribution Non-Commercial License (https://creativecommons.org/licenses/by-nc/4.0) which permits unrestricted non-commercial use, distribution, and reproduction in any medium, provided the original work is properly cited.
키고, 수면잠복시간을 증가시키며 각성도를 높이는 등 수면 에 부정적인 영향을 미치는 것은 잘 알려져 있다. ${ }^{1-3}$ 또한 장 기간 야간 인공조명에 노출되어 발생한 일주기 리듬의 어긋 남(circadian misalignment)은 유방암, 전립선암 등의 암 발 생 증가, 비만율 증가, 심혈관계 질환 및 우울증 등 정신과적 질환의 증가와 관련이 있음이 보고되고 있다. ${ }^{4}$ 코티솔은 일 주기 리듬을 보이는 호르몬이다. ${ }^{5}$ 멜라토닌에 비해 빛에 의한 코티솔의 농도 변화가 크지는 않으나 코티솔이 증가하는 새 벽시간에 10,000 lux 정도의 밝은 빛에 노출되었을 경우 코티 솔 분비가 억제되어서 빛에 대한 감수성은 증명된 바 있다. ${ }^{6}$ 
빛공해 중에서도 야간의 전자매체 사용이 일주기 리듬과 수면, 인지기능 및 심리 등에 미치는 영향에 대한 많은 연구 가 있었다. ${ }^{7.8}$ 조사에 따르면, 전세계적으로 스마트폰 보급이 늘어나면서, 2019년 기준 우리나라 스마트폰 보급률은 92.2\% 이며 매년 스마트폰 이용시간 또한 증가하고 있다. ${ }^{9}$ 특히 습 관적으로 잠들기 전 스마트폰으로 게임, 인터넷, 소셜 네트워 크 서비스 등을 이용하는 현대인들이 점차 많아지고 있으며, 이에 필연적으로 스마트폰이 수면에 미치는 영향의 중요성 이 커지고 있다.

저자들은 이전 연구에서, 야간 조명이 정상인 상근자의 멜 라토닌 분비 및 수면에 미치는 영향을 확인한 바 있다. ${ }^{10,11}$ 이 에 본 연구에서는, 불면증을 호소하는 환자에서 야간 스마트 폰 사용이 수면과 멜라토닌 분비에 미치는 영향을 확인하고 자 하였으며, 피험자의 근무 형태에 따라 다른 반응을 보이는 지도 알아보고자 하여 본 실험을 계획했다. 저자들은 야간 스 마트폰 사용 시 멜라토닌 분비가 억제되고 수면잠복기 지연, 각성지수 증가 및 깊은 수면 감소 등과 같이 수면의 질이 저 하되며, 교대근무자보다 상근자에서 이러한 변화가 두드러 질 것으로 가설을 세웠다.

\section{방 법}

\section{연구대상 및 실험계획}

본 연구는 교차계획설계(cross-over design) 연구이다. 2명 의 피험자는 일주일 간격으로 총 2회 빛조절 실험실(light control unit)을 방문하였으며, 첫 번째 방문 시에 무작위로 스마
트폰 사용군 또는 미사용군으로 배정되었다. 일주일 뒤 두 번째 방문 시, 각각의 피험자는 첫 번째 방문 시와 반대의 군 으로 배정되었다(Fig. 1). 스마트폰 미사용일에는 취침 전까 지 스마트폰, 컴퓨터, TV를 포함한 일체의 전자기기 사용이 금지되며 150 lux의 천장 조명에서 책 또는 신문을 읽도록 했 다. 청색광 필터는 적용하지 않고 중간 정도 밝기로 암실에서 스마트폰 사용 시 눈높이에 조사되는 빛은 5 10 lux로 측정 되었다. 체내 멜라토닌(melatonin)과 코티솔(cortisol) 측정을 위하여, 18:00부터 24:00까지 30분 간격으로 총 13차례 타액 을 채취하였다. ${ }^{11,12}$ 타액 멜라토닌 검출 후 피험자가 취침을 원하는 시간에 소등했으며, 이후 $5 \operatorname{lux}$ 이하 암실에서 수면을 취했고, 수면다원검사를 시행하여 관찰했다. 다음 날 기상 시간은 자유롭게 허용했다. 스마트폰 사용일에는 소등 직전 까지 천장 조명 $150 \mathrm{lux}$ 아래에서 원하는 자세로 제한 없이 스마트폰을 사용하게 했다.

피험자는 첫 번째 검사를 시행하는 날 검사 시작 전에 한글 판 피츠버그수면질지수(Pittsburgh sleep quality index, PSQI), 불면증심각도(insomnia severity index, ISI), 엡워스졸음척도 (Epworth sleepiness scale, ESS)를 작성하였다. ${ }^{13-15}$

본 연구에 사용된 연구 기준, 방법 및 평가는 삼성서울병원 기관윤리심의위원회의 심의(승인번호 2018-10-037)와 동의 면제 승인을 획득하였으며, 기관윤리심의위원회의 관리감독 하에 시행되었다.

\section{자료수집 및 분석 방법}

타액 멜라토닌 및 코티솔 측정을 위해 Salivette ${ }^{\circledR}$ (Sarstedt,

Time of day

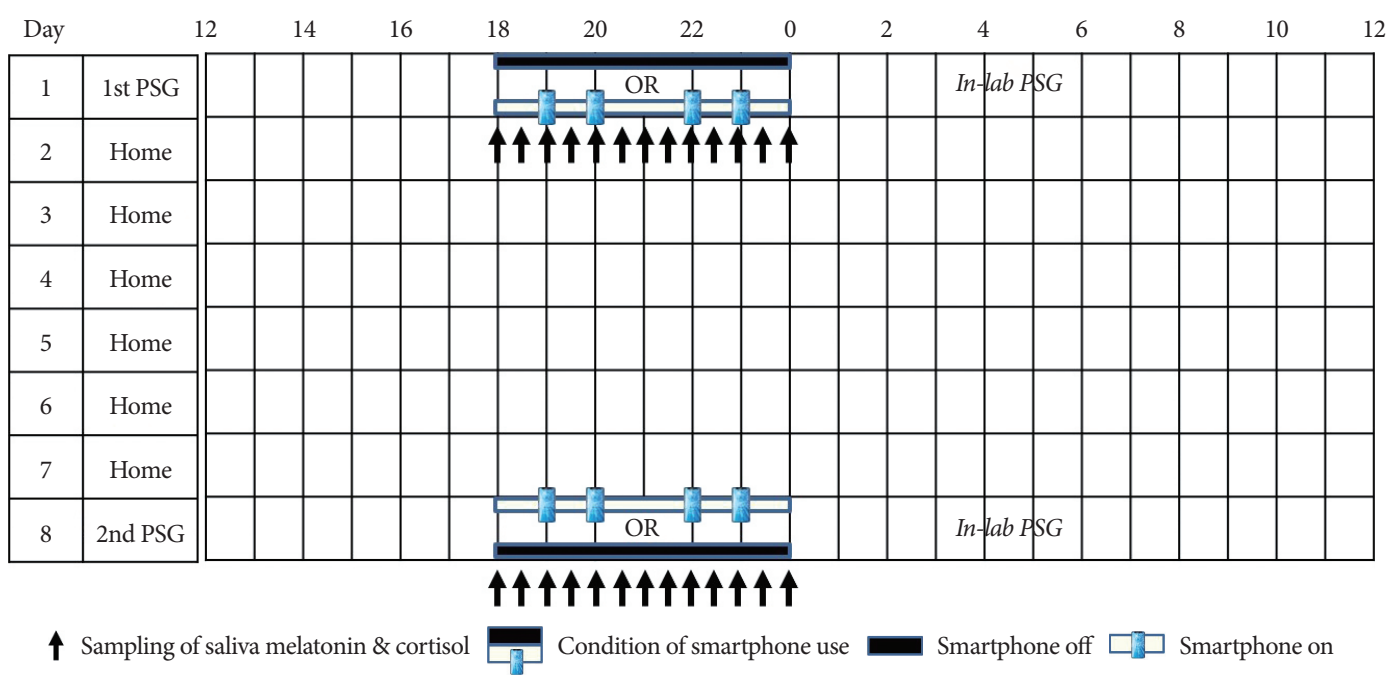

Figure 1. Illustration of the study protocol. Patients were admitted to the light control unit before 18:00. During the evening, they watched their smartphone or just read the book or newspaper (strictly prohibited electronic devices) in a random order. Salivary melatonin was collected every 30 minutes. After midnight, they went to sleep, which was monitored by PSG, and woke up in the morning ad libitum. After one week, patients underwent the same experiment under the other condition. PSG: polysomnography. 
Nümbrecht, Germany) 용기를 이용하여 시간별로 타액을 수집하고 냉동보관 하였으며, 다음날 검사실로 검체를 이송 하였다. 액체크로마토그래피-텐덤질량분석법(liquid chromatography-tandem mass spectrometry)을 활용하여 타액 멜라토닌 및 코티솔 농도를 동시에 측정하였고, 최소 검출농 도는 각각 $0.5 \mathrm{pg} / \mathrm{mL}, 0.05 \mathrm{ng} / \mathrm{mL}$ 였다..$^{2}$ 멜라토닌 농도가 상 승하기 전 기저 멜라토닌 농도를 3회 측정하여 평균값을 구 하고, 평균+2 standard deviation(SD)를 초과하는 시점을 $\mathrm{dim}$ light melatonin onset(DLMO)으로 정의하였다. ${ }^{16}$ 두 군의 타 액 멜라토닌 농도 비교를 위해 사다리꼴 공식(linear trapezoid method)을 이용하여 곡선하면적(the area under the curve, $\mathrm{AUC)}$ )을 계산하였다.

\section{수면다원검사}

Embla N7000(Medcare-Embla ${ }^{\circledR}$, Reykjavík, Iceland) 장 비를 사용하여 수면다원검사를 시행하였다. 6채널의 뇌파 (C3-A2, C4-A1, F3-A2, F4-A1, O1-A2, O2-A1)와 4채널 의 안전위도(electro-oculogram), 1 채널의 턱근전도(chin electromyogram)를 기록하여 수면과 각성 빈도를 측정하였 다. 호흡관련 측정을 위해 구비강열전대(oronasal thermistor) 와 코압력변환기(nasal pressure transducer)를 사용하였고, 흥부와 복부의 호흡유도 체적변동기록기(respiratory inductive plethysmography)를 사용하여 호흡노력을 측정하였다. 그 외 산소포화도 측정기, 심전도, 코골이 소리센서, 2 채널의 양측 전경골근(anterior tibialis)의 근전도, 수면자세를 확인 하는 체위 센서 및 심전도를 포함하였다.

수면 단계와 호흡지수, 사지운동 지수 등 수면다원검사 평 가는 American Academy of Sleep Medicine Manual에 따라 판독하였다. ${ }^{17}$ 수면 양상은 총 침상시간(time in bed), 총 수면 시간(total sleep time), 수면잠복기(sleep onset latency), 렘수 면잠복기(rapid eye movement sleep latency), 입면 후 각성 시간(wakefulness after sleep onset), 수면 효율(sleep efficien$\mathrm{cy}$ )로 측정하였고, 총 각성지수(total arousal index) 및 호흡각 성지수(respiratory arousal index), 자발각성지수(spontaneous arousal index), 운동각성지수(movement arousal index) 를 추가로 평가하였다.

\section{결 과}

첫 번째 피험자는 53세 여자로 수 년 전부터 잠들기 어렵 고 자주 깨는 증상을 호소했다. 08:00부터 12시간 동안 판매 영업직에 종사하면서 자기 직전까지 영업과 관련하여 스마 트폰을 사용하였다. 고혈압, 당뇨로 약물치료 중이었으며, 정
신과적 질환력은 없었다. 평일에는 23:00에 취침하여 30분 후에 잠이 드나, 휴일에는 23:50에 누워도 잠이 오지 않아서 스마트폰을 보다가 02:00 즈음에 잠을 청하는데, 평균 1시간 후 잠이 든다고 하였다. 피츠버그수면질지수(PSQI)는 14점, 불면증심각도(ISI)는 17점으로 높았으며, 스탠포드졸음척도 (Stanford sleepiness scale, SSS) 2점, 엡워스졸음척도(ESS) 3점으로 주간졸림은 호소하지 않았다.

저녁 시간에 스마트폰을 사용한 날의 DLMO는 스마트폰 미사용 날에 비해 30분 지연되었고(21:30 vs. 22:00), 멜라토 닌 분비량을 반영하는 AUC는 $38.7 \%$ 감소했다(Fig. 2A, 3). 타액 내 코티솔은 양일 모두 비슷한 수준으로 취침 전까지 감소하는 양상이었다. 수면다원검사에서 스마트폰 사용일의 수면잠복기는 2 분, 스마트폰 미사용일에는 5 분으로 양일 모 두 정상 범위였다. 양일 모두 수면호흡장애가 관찰되었고(apnea-hypopnea index, AHI 22.7 vs. 14.0), 주기적다리떨림증 (periodic limb movement index, PLMI 25.5 vs. 14.7/h)이 관 찰되었다(Table 1). 수면도(hypnogram)에서 스마트폰 미사 용일에 비해 사용일에서 REM 잠복기가 짧아지고 REM \%가 증가한 결과를 보였다(Fig. 4A).

두 번째 피험자는 50세 남자로 20년 간 버스운전기사로 1일 2교대 근무하고 있다. 근무시간은 04:00 13:00 또는 13:00 22:00이나 상황에 따라 자주 변경된다고 한다. 5년 전 직장암 으로 수술받은 병력 외 특이사항은 없었다. $\mathrm{BDI}$ 는 15점으로 경한 우울감을 호소했다. 평일에는 21:00, 휴일에는 02:00에 자려고 눕지만 잠들기까지 2 3시간이 걸린다고 하였고, 평 일에는 2 3시간, 주말에는 4 5시간 밖에 못 잔다고 호소하 였다. 잠이 오지 않아 스마트폰을 사용하기도 하나, 폰을 보 다가 잠드는 시간을 놓치는 경우가 많다고 했다. 그 외 낮에 도 운전하는 시간 외에는 거의 하루 종일 스마트폰 게임을 하 고 있다고 한다. PSQI 13점, ISI 16점으로 상승하였고, SSS 3점, ESS 4점으로 주간졸림은 보고하지 않았다.

스마트폰 사용일과 미사용일 모두 주간근무를 마친 후 검 사실로 입실하도록 했다. 그럼에도 불구하고 본 피험자의 시 간에 따른 타액 멜라토닌과 코티솔의 농도 변화는 일반적인 형태를 보이지 않았다. 스마트폰 미사용일에는 취침 시간에 가까워질수록 멜라토닌 농도가 상승했으나, $\mathrm{DLMO}$ 를 결정 하는 급격한 증가 시점을 찾을 수 없었다. 스마트폰 사용일에 는 21:00부터 22:00까지 급격히 멜라토닌 농도가 감소했다가, 22:30부터 상승했으나 DLMO의 정의에 만족할 시간대가 없 었다(Fig. 2B). 타액 내 코티솔도 취침시간에 가까워질수록 농도가 감소하는 정상적인 양상이 아닌, 취침 1 2시간 전 농 도가 상승하는 비전형적인 모습을 보였다. 수면다원검사의 수면잠복기는 스마트폰 사용일, 미사용일에 각각 2 분, 0.5 분 

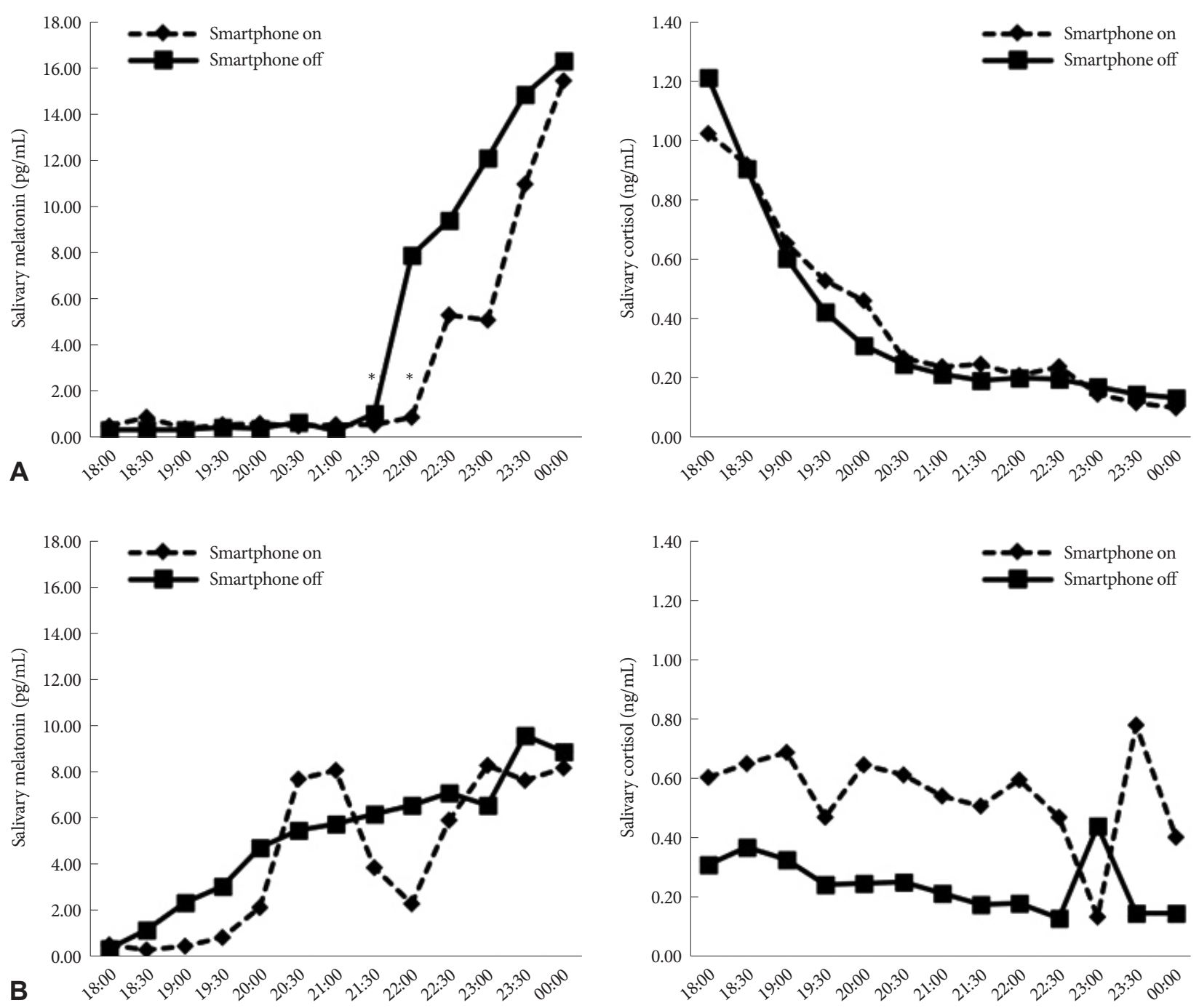

Figure 2. Salivary melatonin and cortisol level of $(A)$ day worker and $(B)$ shift worker. *dim light melatonin onset.

으로 정상 범위였다. N3 수면은 양일 모두 매우 떨어져 있었 고, 각성지수도 모두 증가하였다(Table 1). 반면, 다음날 피험 자는 주관적인 수면잠복기 60분, 수면시간은 2 3시간으로 기록하여 객관적인 수면다원검사 지표와 큰 차이를 보였다. 수면도에서 양일 모두 렘수면이 수면 초반부터 나타나는 등 비정상적인 수면 주기를 보였다(Fig. 4B).

\section{고 찰}

1980년 처음으로 사람에서 인공 빛에 의해 멜라토닌 분비 가 억제된다는 것이 밝혀진 이후로, ${ }^{1}$ 여러 연구에서 빛노출이 멜라토닌 분비 및 수면에 미치는 영향에 대한 논의가 있어 왔 다. 빛의 세기에 따라 멜라토닌 분비가 억제되는 역의 상관 관계를 보이며, ${ }^{18}$ 빛의 스펙트럼 중에서도 파란색으로 보이는 446 477 nm의 단파장 부분이 가장 강력히 멜라토닌을 억제
하는 것으로 알려져 있다. ${ }^{19,20}$ 하지만 다양한 실험조건에서 야간 빛 노출에 의한 체내 멜라토닌과 수면다원검사 지표 변 화는 일관된 결과를 보이지 않는다. Cajochen 등은 취침 전 5시간 동안 발광다이오드(light emitting diode, LED) 또는 non-LED 컴퓨터에 노출시켜 연구를 수행하였는데, 단파장 영역대 방출이 2 배 이상 많은 LED 컴퓨터 사용 동안 멜라토 닌 분비가 억제되고 주관적, 객관적 졸림이 감소하며, 주의 집중력, 기억력과 같은 인지기능이 높아져 수면을 방해함을 보고하였다. ${ }^{21}$ 하지만 야간에 서로 다른 색온도의 TV 시청 후 멜라토닌을 측정한 연구에서 시청 시간 및 색온도는 멜라토 닌 농도에 유의한 영향을 미치지 못했다. ${ }^{22}$ 또한 청색광 억제 기술을 적용한 LCD TV를 사용한 연구에서는 일반 LCD TV 보다 멜라토닌 억제가 적었지만, ${ }^{3}$ 청색광을 억제한 LED 스 마트폰 사용 시 일반 LED와 비교하여 혈중 멜라토닌과 코티 솔 농도의 차이는 보이지 않는 등 청색광 억제 디스플레이의 
효능에 대한 서로 다른 결과가 발표되었다. ${ }^{24} \mathrm{LED}$ 광원에 비 해 청색광을 $1 / 3$ 로 줄인 유기발광다이오드(organic light emitting diode) 광원을 천장조명으로 설치하여 저녁 시간 내내 노 출시키면서 체내 멜라토닌, 코티솔, 수면 및 각성도의 변화를 비교했을 때에도 LED 조명에 비해 유의한 멜라토닌 농도 등

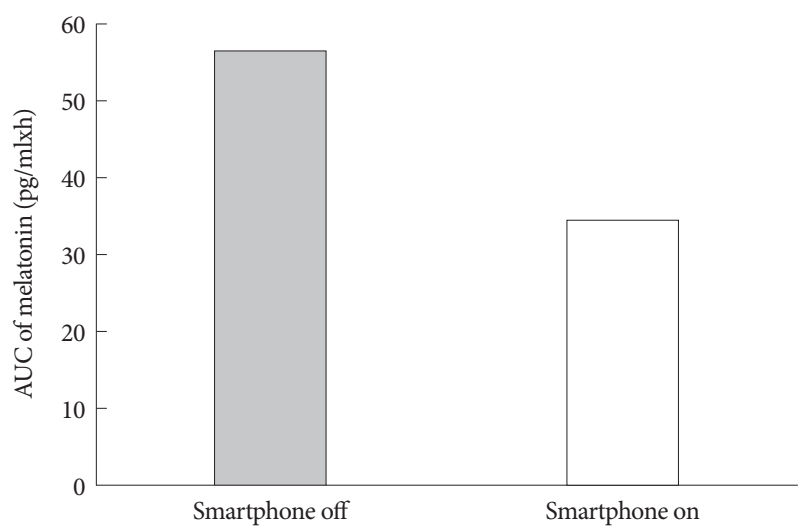

Figure 3. Comparison of the concentration of salivary melatonin with or without smartphone use in the day worker. The AUC in smartphone on condition decreased $38.7 \%$ compared to smartphone off condition. AUC: area under the curve.
의 변화가 관찰되지 않았다. ${ }^{11}$ 이는 광원의 종류와 강도뿐만 아니라, 광원의 크기, 위치(노출 거리), 노출 시간 등에 의하여 수면과 멜라토닌 분비에 미치는 영향이 달라질 수 있음을 시 사한다.

야간 빛 노출이 수면다원검사 지표에 미치는 영향에 관한 연구는 멜라토닌 연구에 비해 수가 적고 일관성이 더 떨어지 며, 논란의 여지가 있다. 본 연구진이 2013년 시행한 연구에 서는 취침 중 빛 노출(40 lux)이 잦은 각성을 유발하고 $\mathrm{N1}$ 증 가, N3 감소를 야기하였으나 REM 수면에 미치는 영향은 뚜 렷하지 않았다. ${ }^{10}$ 하지만 $\mathrm{Cho}$ 등이 시행한 연구에서 취침 중 희미한 빛(5 또는 10 lux)으로도 N1 증가, N2 감소 외 REM 수면 증가 및 REM density는 감소하는 경향과 같은 REM 수면의 변화를 보고하였으며, ${ }^{25}$ Chang 등은 이와 반대로 취 침 전 종이책보다 전자책(30 50 lux)을 본 경우 REM 수면이 감소하고 non-REM 수면은 두 군 간 차이가 없음을 보고하 였다. ${ }^{26}$ 야간에 서로 다른 파장의 빛 노출이 수면다원검사 결 과에 미치는 영향에 관한 연구에서는 non-REM 또는 REM 수면의 분포에 미치는 영향은 없었고, 전구색 $(2500,3000 \mathrm{~K})$ 에 비해 주광색 $(6500 \mathrm{~K})$ 빛에 노출 시 non-REM 수면 중

Table 1. Polysomnographic parameters of day worker and shift worker with or without smartphone use

\begin{tabular}{|c|c|c|c|c|}
\hline \multirow{2}{*}{ Parameters } & \multicolumn{2}{|c|}{ Day worker } & \multicolumn{2}{|c|}{ Shift worker } \\
\hline & Smartphone on & Smartphone off & Smartphone on & Smartphone off \\
\hline Light off & $00: 42$ & $00: 56$ & $00: 50$ & $00: 52$ \\
\hline Light on & $06: 49$ & 07:00 & $06: 28$ & $06: 47$ \\
\hline Time in bed, min & 367 & 364 & 337.5 & 356 \\
\hline Total sleep time, min & 350 & 334 & 315 & 332 \\
\hline Sleep onset latency, min & 2 & 5 & 2 & 0.5 \\
\hline REM latency, min & 35.5 & 49 & 13 & 3.5 \\
\hline Sleep efficiency, \% & 95.4 & 91.8 & 93.3 & 93.3 \\
\hline N1 sleep, \% & 15.1 & 25.0 & 14.4 & 8.6 \\
\hline N2 sleep, \% & 46.2 & 45.9 & 49.1 & 60.1 \\
\hline N3 sleep, \% & 2.4 & 2.5 & 0 & 0.8 \\
\hline REM sleep, \% & 36.3 & 26.6 & 36.5 & 30.6 \\
\hline WASO, min (\%) & $15.0(4.1)$ & $25.0(7.0)$ & $20.5(6.1)$ & $23.5(6.6)$ \\
\hline AHI, /h & 22.7 & 14.0 & 1.5 & 1.4 \\
\hline Lowest oxygen saturation, \% & 82 & 87 & 93 & 93 \\
\hline Snoring & Light & Very light & Very light & Very light \\
\hline $\mathrm{AI}, / \mathrm{h}$ & 14.7 & 16.5 & 15.6 & 10.5 \\
\hline Respiratory AI, /h & 7.0 & 5.7 & 1.1 & 0.9 \\
\hline Spontaneous AI, /h & 3.4 & 4.1 & 6.9 & 7.4 \\
\hline PLMI, /h & 25.5 & 14.7 & - & - \\
\hline MAI, /h & 1.4 & 2.7 & - & - \\
\hline
\end{tabular}

REM: rapid eye movement, WASO: wakefulness after sleep onset, AHI: apnea-hypopnea index, AI: arousal index, PLMI: periodic limb movement index, MAI: movement arousal index 

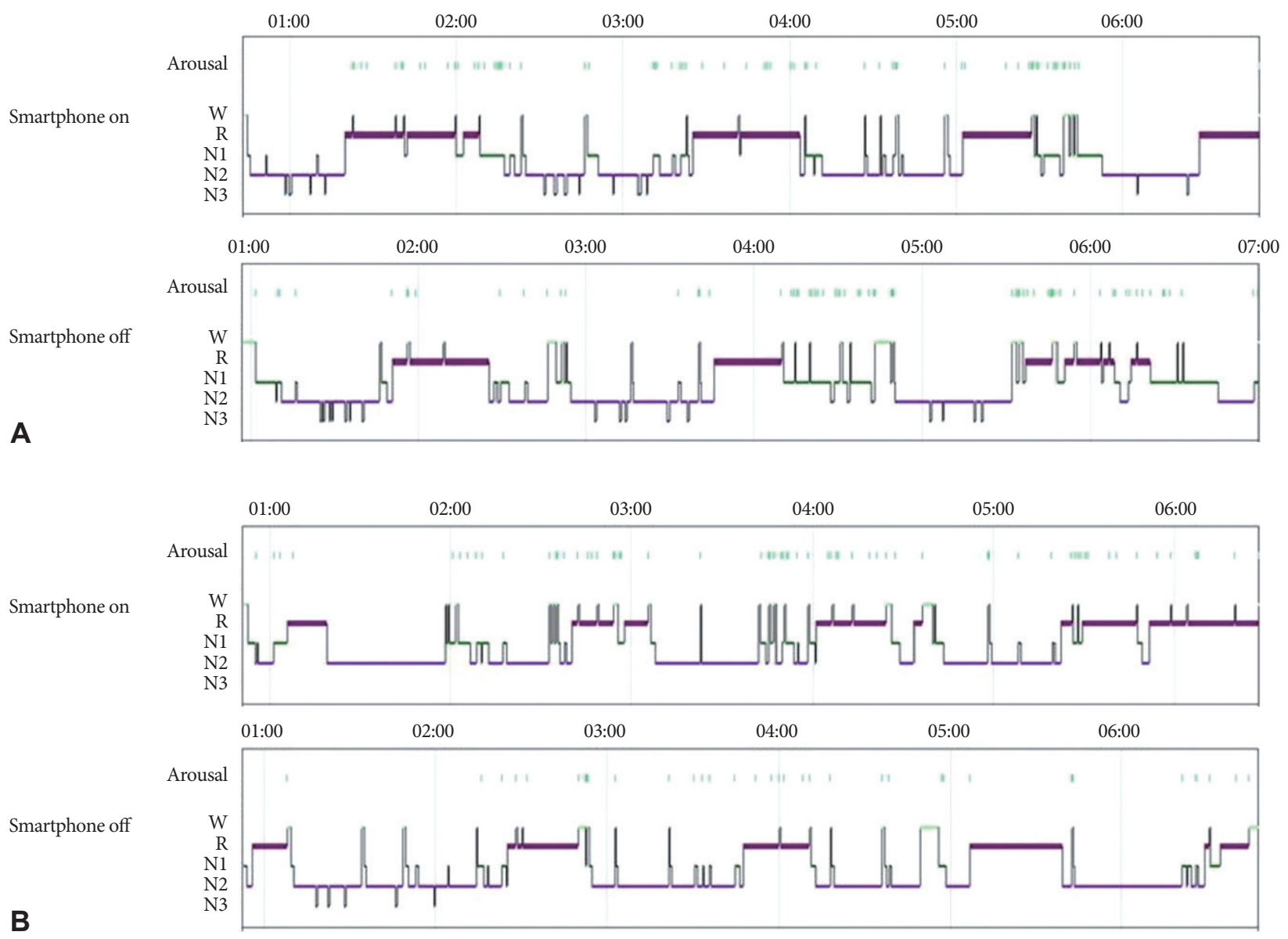

Figure 4. Illustration of hypnograms of the day worker and shift worker with or without smartphone use. (A) Hypnograms of day worker show earlier REM sleep latency and increased REM \% with smartphone use and slightly increased WASO without smartphone use. (B) Hypnograms of shift worker show decreased REM latency in both conditions and abnormal sleep cycle with smartphone use. W: waking, R: REM sleep, N1: N1 sleep, N2: N2 sleep, N3: N3 sleep, REM: rapid eyeball movement, WASO: wakefulness after sleep onset.

slow wave activity가 감소함을 보고하였다. ${ }^{27}$ 물론 위 연구들 은 모두 다른 실험 조건에서 이뤄졌으나, 단시간 취침 전 또 는 취침 중 빛 노출이 수면다원검사 지표에 미치는 영향은 상대적으로 적어서 상반된 결과를 보였을 수 있을 것으로 사 료된다. 이는 수면다원검사 지표보다는 멜라토닌 농도가 단 시간 야간 빛 노출이 수면에 미치는 영향을 더 잘 반영할 수 있는 표지자임을 시사한다.

이전의 연구는 대부분 수면장애를 호소하지 않는 건강한 성인에서 수행되었다. 반면, 본 연구에서는 만성 불면증을 호소하는 환자들이 야간에 장시간 스마트폰을 사용했을 때 멜라토닌과 수면에 미치는 영향을 보고자 했고, 특히 교대근 무자를 포함시켜서 교대근무로 교란된 일주기 리듬에 야간 빛 노출이 어떻게 작동하는지 보고자 하였다. 환자들은 평소 $1 \sim 3$ 시간 이상의 길어진 수면잠복 시간을 호소했는데, 실제 수면다원검사에서는 정상보다 오히려 짧아진 수면잠복기를 보여 수면 상태 오인의 가능성을 시사하였다. 또는 평소보다 실험실 환경에서 취침시간이 늦어지면서 수면제한의 효과로
수면잠복기가 감소하고 REM 잠복기가 짧아졌을 가능성이 있다. 본 연구에서도 상근자 불면증 환자에서 야간 스마트폰 사용일에 DLMO가 지연됨으로써 취침시간 전까지 분비된 멜라토닌 양(AUC)이 감소, 즉 멜라토닌 분비가 억제되는 것 을 확인하였다. 야간 전자매체 사용이 수면에 영향을 미치는 기전은 여러가지가 있을 수 있는데, 전자기기 사용으로 인한 실직적인 취침 시간 감소, 취침 전 전자기기 사용으로 인한 정신적, 감정적, 생리적 각성 유발, 전자기기에서 방출되는 빛 등이 그 것이다. ${ }^{7}$ 비록 스마트폰에서 방출되는 빛이 눈높 이에 도달하여 측정되는 조도는 5 10 lux로 높지 않았지만 멜라토닌 분비에 중요한 야간에 장시간의 $\mathrm{LED}$ 화면 노출은 생체 시계(biologic clock)를 교란시키고 일주기 리듬을 지연 시키는 데는 충분할 수 있다. 본 증례에서는 환경 조명 150 lux를 사용하였는데 dim light 조건 하에서는 더 뚜렷한 차이 를 보이는 결과를 얻을 수도 있을 것으로 사료된다. 교대근 무자에서 멜라토닌 농도는 수면 각성 패턴과 일치하지 않아 $\mathrm{DLMO}$ 이전에 잠들기도 하고, 하루 중 상승 곡선이 여러 차 
례 보이는 등 변동성을 보이는 것이 특징이다. ${ }^{28}$ 본 연구의 교 대근무자에서는 스마트폰 사용과 관계없이 멜라토닌 및 코 티솔 분비가 비정상적인 양상을 보였는데, 24시간 연속으로 멜라토닌을 측정하지 않았기 때문에 정확한 일주기 리듬을 평가하는 데 제한이 있으며 DLMO가 이미 지난 시점부터 멜라토닌 농도가 측정되었을 가능성이 있다. 또는 교대근무 로 인해 이미 일주기 리듬이 교란되어 스마트폰이 멜라토닌 분비에 미치는 영향이 뚜렷하지 않았을 수 있다. 하지만 이 결과가 교대근무자에서 취침 전 스마트폰 사용이 수면에 미 치는 영향이 없음을 뜻하는 것은 아니며 오히려 깊은 잠을 방해하고 수면 장애를 더욱 악화시키는 요인이 될 수 있으므 로 이에 대한 후속연구가 필요하겠다.

본 연구의 수면다원검사 결과는 상근자에서 스마트폰 미 사용일에 비해 사용일에 총 수면시간, 수면효율 및 REM 수 면시간이 약간 증가하고 수면 중 각성 및 각성지수가 감소하 는 등 가설과 상반된 결과를 보였다. 이러한 결과는 본 연구 의 제한점과 관련이 있을 것으로 보인다. 제한점은 다음과 같다. 첫째, 하루가 채 되지 않는 시간 동안 검사 환경을 조성 했기에 실험 조건이 수면다원검사 결과에 영향을 주기에는 미미할 수 있다. 둘째, 환경 조명 $150 \mathrm{lux}$ 하의 스마트폰 조 도는 $10 \mathrm{lux}$ 밖에 되지 않아 빛의 세기에 따른 수면다원검사 지표에의 영향이 충분히 크지 않았을 가능성이 있다. 또한 전자책과 비교할 때 스마트폰의 경우 시청거리를 고정한 채 사용하기 어려워 망막에 도달하는 빛의 양을 일정하게 유지 하기 힘들다는 한계가 있다. 셋째, 액티와치나 수면일지를 작 성하지 않았기에 주간 빛 노출이나 검사 전 규칙적인 수면 스케줄을 지켰는지 확인할 수 없었던 점을 들 수 있다. 넷째, 상근자는 수면호흡장애와 주기성사지운동장애가 발견되었 기에 수면장애가 수면의 질에 미치는 영향을 배제할 수 없었 다. 다섯째, 본 연구에서는 스마트폰으로 소비하는 컨텐츠를 지정하지 않았는데, 컨텐츠 내용에 따라 일주기 리듬의 변화 가 다르게 나타날 수 있다. Higuchi 등은 이전 연구에서 지루 한 것보다 흥미를 자극하는 컨텐츠를 밝은 디스플레이로 소 비할 때, 어두운 디스플레이나 지루한 컨텐츠를 소비할 때보 다 멜라토닌이 유의하게 억제됨을 보고하였다. ${ }^{29}$ 마지막으로 환자 수가 적어 통계적인 유의성을 확인하지 못하였다. 그럼 에도 본 연구는 처음으로 불면증 환자에서 스마트폰 사용 유 무에 따른 멜라토닌 분비 변화를 관찰하고 수면다원검사를 시행하여 객관적인 수면 지표를 비교했다는 점에 의의가 있 으며, 불면증 환자에서 일주기 리듬을 교란시키고 나아가 수 면의 질을 악화시킬 위험이 있는 야간 스마트폰 사용에 대해 경각심을 가지고 많은 표본 수를 확보하여 후속연구를 할 필요가 있다. 또한 스마트폰이 정상 성인 또는 소아청소년의
멜라토닌 분비와 수면에 미치는 영향 및 야간 스마트폰 사용 이 불면증을 유발하는 요인이 될 수 있는지의 인과관계를 확 인하기 위한 연구가 필요하겠다.

\section{Acknowledgments}

This study was supported by Samsung Medical Center Grant (\#OTC1190671).

\section{Conflicts of Interest}

The authors have no potential conflicts of interest to disclose.

\section{ORCID iDs}

Hyunjin Jo

Su Jung Choi

Eun Yeon Joo

\section{Dongyeop Kim}

https://orcid.org/0000-0001-6045-0693 https://orcid.org/0000-0001-9563-1849 https://orcid.org/0000-0003-2171-7441 https://orcid.org/0000-0003-1233-959X

\section{Author Contributions}

Conceptualization: Eun Yeon Joo, Hyunjin Jo. Data curation: Eun Yeon Joo, Su Jung Choi. Formal analysis: Dongyeop Kim, Su Jung Choi. Investigation: Dongyeop Kim, Hyunjin Jo. Methodology: Eun Yeon Joo. Supervision: Eun Yeon Joo, Su Jung Choi. Writing_original draft: Dongyeop Kim. Writing-review \& editing: Eun Yeon Joo, Su Jung Choi.

\section{REFERENCES}

1. Lewy AJ, Wehr TA, Goodwin FK, Newsome DA, Markey SP. Light suppresses melatonin secretion in humans. Science 1980;210:1267-1269. https://doi.org/10.1126/science.7434030.

2. Badia P, Myers B, Boecker M, Culpepper J, Harsh JR. Bright light effects on body temperature, alertness, EEG and behavior. Physiol Behav 1991;50:583-588. https://doi.org/10.1016/0031-9384(91)90549-4.

3. Cajochen C, Kräuchi K, Danilenko KV, Wirz-Justice A. Evening administration of melatonin and bright light: interactions on the EEG during sleep and wakefulness. J Sleep Res 1998;7:145-157. https://doi. org/10.1046/j.1365-2869.1998.00106.x.

4. Cho Y, Ryu SH, Lee BR, Kim KH, Lee E, Choi J. Effects of artificial light at night on human health: a literature review of observational and experimental studies applied to exposure assessment. Chronobiol Int 2015;32:1294-1310. https://doi.org/10.3109/07420528.2015.1073158.

5. Weitzman ED, Zimmerman JC, Czeisler CA, Ronda J. Cortisol secretion is inhibited during sleep in normal man. J Clin Endocrinol Metab 1983;56:352-358. https://doi.org/10.1210/jcem-56-2-352.

6. Jung CM, Khalsa SB, Scheer FA, et al. Acute effects of bright light exposure on cortisol levels. J Biol Rhythms 2010;25:208-216. https://doi. org/10.1177/0748730410368413.

7. Lemola S, Perkinson-Gloor N, Brand S, Dewald-Kaufmann JF, Grob A. Adolescents' electronic media use at night, sleep disturbance, and depressive symptoms in the smartphone age. J Youth Adolesc 2015;44: 405-418. https://doi.org/10.1007/s10964-014-0176-x.

8. Cain N, Gradisar M. Electronic media use and sleep in school-aged children and adolescents: a review. Sleep Med 2010;11:735-742. https:// doi.org/10.1016/j.sleep.2010.02.006.

9. Ministry of Science and ICT, National Information Society Agency. Internet Usage Survey of Korea 2019. Daegu: National Information Society Agency, 2019;95.

10. Cho JR, Joo EY, Koo DL, Hong SB. Let there be no light: the effect of bedside light on sleep quality and background electroencephalographic rhythms. Sleep Med 2013;14:1422-1425. https://doi.org/10.1016/ j.sleep.2013.09.007.

11. Park HR, Choi SJ, Jo H, Cho JW, Joo EY. Effects of evening exposure to light from organic light-emitting diodes on melatonin and sleep. J Clin 
Neurol 2020;16:401-407. https://doi.org/10.3988/jcn.2020.16.3.401.

12. Shin S, Oh H, Park HR, Joo EY, Lee SY. A sensitive and specific liquid chromatography-tandem mass spectrometry assay for simultaneous quantification of salivary melatonin and cortisol: development and comparison with immunoassays. Ann Lab Med 2021;41:108-113. https:// doi.org/10.3343/alm.2021.41.1.108.

13. Cho YW, Song ML, Morin CM. Validation of a Korean version of the insomnia severity index. J Clin Neurol 2014;10:210-215. https://doi. org/10.3988/jcn.2014.10.3.210.

14. Cho YW, Lee JH, Son HK, Lee SH, Shin C, Johns MW. The reliability and validity of the Korean version of the Epworth Sleepiness Scale. Sleep Breath 2011;15:377-384. https://doi.org/10.1007/s11325-010-0343-6.

15. Sohn SI, Kim DH, Lee MY, Cho YW. The reliability and validity of the Korean version of the Pittsburgh Sleep Quality Index. Sleep Breath 2012;16:803-812. https://doi.org/10.1007/s11325-011-0579-9.

16. Benloucif S, Burgess HJ, Klerman EB, et al. Measuring melatonin in humans. J Clin Sleep Med 2008;4:66-69. https://doi.org/10.5664/ jcsm. 27083.

17. Berry RB, Brooks R, Gamaldo C, et al. AASM scoring manual updates for 2017 (Version 2.4). J Clin Sleep Med 2017;13:665-666. https://doi. org/10.5664/jcsm.6576.

18. Mclntyre IM, Norman TR, Burrows GD, Armstrong SM. Human melatonin suppression by light is intensity dependent. J Pineal Res 1989;6: 149-156. https://doi.org/10.1111/j.1600-079x.1989.tb00412.x.

19. West KE, Jablonski MR, Warfield B, et al. Blue light from light-emitting diodes elicits a dose-dependent suppression of melatonin in humans. J Appl Physiol (1985) 2011;110:619-626. https://doi.org/10.1152/ japplphysiol.01413.2009.

20. Wood B, Rea MS, Plitnick B, Figueiro MG. Light level and duration of exposure determine the impact of self-luminous tablets on melatonin suppression. Appl Ergon 2013;44:237-240. https://doi.org/10.1016/ j.apergo.2012.07.008.
21. Cajochen C, Frey S, Anders D, et al. Evening exposure to a light-emitting diodes (LED)-backlit computer screen affects circadian physiology and cognitive performance. J Appl Physiol (1985) 2011;110:14321438. https://doi.org/10.1152/japplphysiol.00165.2011.

22. Figueiro MG, Wood B, Plitnick B, Rea MS. The impact of watching television on evening melatonin levels. J Soc Inf Disp J Soc Inf Display 2013;21:417-421. https://doi.org/10.1002/jsid.200.

23. Komada Y, Aoki K, Gohshi S, Ichioka H, Shibata S. Effects of television luminance and wavelength at habitual bedtime on melatonin and cortisol secretion in humans. Sleep Biol Rhythms 2015;13:316-322. https:// doi.org/10.1111/sbr.12121.

24. Heo JY, Kim K, Fava M, et al. Effects of smartphone use with and without blue light at night in healthy adults: a randomized, double-blind, cross-over, placebo-controlled comparison. J Psychiatr Res 2017;87:6170. https://doi.org/10.1016/j.jpsychires.2016.12.010.

25. Cho CH, Lee HJ, Yoon HK, et al. Exposure to dim artificial light at night increases REM sleep and awakenings in humans. Chronobiol Int 2016;33:117-123. https://doi.org/10.3109/07420528.2015.1108980.

26. Chang AM, Aeschbach D, Duffy JF, Czeisler CA. Evening use of lightemitting eReaders negatively affects sleep, circadian timing, and nextmorning alertness. Proc Natl Acad Sci U S A 2015;112:1232-1237. https://doi.org/10.1073/pnas.1418490112.

27. Chellappa SL, Steiner R, Oelhafen P, et al. Acute exposure to evening blue-enriched light impacts on human sleep. J Sleep Res 2013;22:573580. https://doi.org/10.1111/jsr.12050.

28. Sack RL, Blood ML, Lewy AJ. Melatonin rhythms in night shift workers. Sleep 1992;15:434-441. https://doi.org/10.1093/sleep/15.5.434.

29. Higuchi S, Motohashi Y, Liu Y, Ahara M, Kaneko Y. Effects of VDT tasks with a bright display at night on melatonin, core temperature, heart rate, and sleepiness. J Appl Physiol (1985) 2003;94:1773-1776. https://doi.org/10.1152/japplphysiol.00616.2002. 